\title{
INFLUENCE OF SECURITY THREATS ON TOURISM DESTINATION DEVELOPMENT
}

\author{
Bojan Kurež, Faculty of Tourism, University of Maribor \\ Boris Prevolšek, Faculty of Tourism, University of Maribor
}

\begin{abstract}
The aim of the paper is to analyze the modern security environment and its impact on tourism destination development. Contemporary security environment is a result of historical events affected by the elements of the contemporary safety and political environment. Ground security concepts, which dominate contemporary security environment, are pointed out and further linked to the development of the modern security threats shaping tourism destination development. We are pointing out how the major security threats influence the tourism destination development. Methodology is based on secondary analysis of literature. Several current case studies are made to support conclusions on relationship between security and tourism destination developments.
\end{abstract}

Keywords: Safety, Security, Tourism destination, Development

\section{UTICAJ BEZBEDNOSNIH PRETNJI NA RAZVOJ TURISTIČKE DESTINACIJE}

\begin{abstract}
Sažetak
Cilj rada je analiza savremenog bezbednosnog okruženja i njegovog uticaja na razvoj turističke destinacije. Savremeno bezbednosno okruženje je posledica istorijskih događaja i oblikovano je elementima savremenog koncepta sigurnosti i političkog okruženja. Koncepti kopnene bezbednosti koji dominiraju savremenim bezbednosnim okruženjem se ističu i dalje povezuju sa razvojem savremenih bezbednosnih pretnji, oblikujući razvoj turističkih destinacija. Autori ukazuju na to kako veće pretnje bezbednosti utiču na razvoj turističkih destinacija. Metodologija se zasniva na sekundarnoj analizi literature. Urađeno je nekoliko studija slučaja na savremenim primerima kako bi se podržali zaključci o odnosu između bezbednosti i razvoja turističke destinacije.
\end{abstract}

Ključne reči: sigurnost, bezbednost, turistička destinacija, razvoj

TIMS Acta (2015) 9, 159-168

Introduction

Global society lives in a world shaped by radical changes in the field of communication and information technology (Ovsenik, 1999, p. 290). Despite the development and continuous improvements of everyday life, the security still presents the immanent element of each society. "We face security issues and 
deal with their importance since the early periods of the humankind" (Kurež et al., 2009, p. 170); however its understanding was and still is changing. Security concept is a living form which changes, grows and adapts to different environments, hence it represents the evolution of security concept and its evolution, which is interesting. It is ironing that the evolution of the security concept will continue even beyond the point, when the final collapse of the humankind is to happen, despite the fact that the concept itself is about the processes, mechanisms and systems dealing with the prevention of the collapse.

Security is undoubtedly related to the field of the tourism, and has been so since its origins. The modern travel industry emerged in 1841, when Thomas Cook organized his first travel package from Leicester to Loughborough (UK) to a temperance meeting. Based on the growth of the travel industry in the last 170 years, his trip was a rather simple one, however had to consider main elements of the organized travel industry, which were passed onto contemporary travel packages. Among others, security elements were and still are essential part of this industry.

Global impacts and dimensions of the tourism economy are responsible for strengthening the importance of the security issues from personal to local and global level. Halland others $(2003$, p. 3) report that international travel industry influences the economy and political stability of entire regions, continents and the world. Each time security threats occur at any popular travel destination, travel flows to and from change dramatically. It has been noticed that the latter is even more evident from the Cold War onwards. Since the events on the 9/11 the security issues and safety procedures became an indispensable element of almost every travel we make and they shape global travel flows (Mansfeld \& Pizam, 2006, p.xiii). One of the reasons for such strong connections between the security threats and travel flow changes are modern communication tools. Information arrives to a tourist in minutes after attacks, disputes or other security related events occur, hence the tourist have the opportunity of asses the level of the threat and possibly amend or cancel their travel plans. These reactions show in a drop of visitors, travel expenditure patterns, destination image and other short or long term characteristics. Security treats are thus, immediately after they appear, embedded in every tourism or general economy process of the travel market.

\section{Security treats in tourism}

Security treats evolve as a product of the security environment, even more they shape it; hence it is a living form which changes throughout the history. After the Cold War the nature of treats changed significantly. Armed international conflicts still present the treat; however the importance of other non-military treats increased drastically. The most important nonmilitary threats are: the fragility of the democratic and economic institutions and processes in the former socialist countries and some other great powers; weak level of social-political cohesiveness and stability in some countries; massive violations of human rights; disrespect of the minority rights; ethnic and religious extremism; strong imbalance in the distribution of the wealth and power among global centers and its peripheral areas; strong and powerful subjects with large military-industrial complexes that need tensions in order to maintain their existence; limited natural resources essential for the continuous development of the entire world which could cause the development of exacerbated relations between developed and emerging countries; global social migrations that are consequences of ethnical and religious tensions between different social groups; international organized crime; global environment threats and pollution; spread of lethal diseases; ignorance and egoism of developed world for world-wide problems (Lubi, 2004, pp.190-191).

Alsarayreh and others (2010, pp. 145-147) focused on studying the relations between tourism and politics. Main findings show that global tourism is a major component of the international politics and is subordinate to the ideology. Tourism is under great pressure of wars, political instability, international conflicts and terrorism. As an economy depending on changing the everyday living environment, tourism depends on international politics, policies and relations, thus the stability and peace are crucial for its development. 
All above mentioned security and safety issues emerge from the contemporary security environment and are more or less directly involved in the development of the tourism. Relevant literature (Hall et al; 2003, pp. 5-12; Mansfeld \& Pizam, 2006, pp. 3-4) and our own research point out the different groups of security treats within tourism: crime, terrorism, war, social and political unrests, environmental threats and the spread of infectious diseases.

\section{Crime}

Crime certainly is one of the most serious treats to the modern tourism. Mc Peters and Stronge report in their early study from Miami, that the level of the economy and property related crime activities changes according to the tourism activity. The level of crime faced significant increase during the peak tourist season and secondly the level of crime was much higher in the tourist then other areas (Brunt et al., 2000, p. 417). There are different forms of tourism related crime actions; pick pocketing, shoplifting, rapes, murders, kidnappings, piracy to name only a few. It can be either domestic against tourist or tourist against domestic population but sometimes also tourist against tourist population related crime actions. Pečar (1999, p. 320) says that tourist environment causes so called ambivalent feelings, needs, demands, expectations and other emotions. Destination as a different living environment enables people to act differently in many cases in a way which is totally unacceptable in their home environments. Due to their relaxation, feelings of freedom and not lack of control tourists surrender themselves to situations and actions which cause unknown comfort. In many cases they even forget their physical, health and financial safety. Tourist destination for many people represents a possibility for victimization. Another interesting point was made by Ryan and Kinder (Brunt et al., 2000. p. 418) who claim that both tourism and crime should be considered as deviant behavior, the tourism being desirable and crime not.

Drug trafficking is considered to be one of the most wide spread crime forms and the number of groups involved in such actions increase (Dobovšek,
2005). Due to the potential size of the demand market it is impossible to monopolize this form of crime, hence investigating and preventing are difficult. There are many ways to link tourism with this form of crime, since there are travel destinations worldwide, which tourists visit to enroll in such crime actions. Tourists acteither as consumers, traffickers or sellers of drugs during peak seasons when border controls cannot perform sufficient control. Tourists are impossible to be isolated from drug trafficking and the destination, even if some would want that, on the other hand there are destinations allowing drug use, so tourist would visit them to experience that .

At the emergence of the organized crime, prostitution was the most profitable form of crime. Today, this form of crime is no longer as profitable; however it influences the spread of other related forms of crime. Prostitution was always closely related to the tourism, while similar to the drug experience tourist would seek sexual comfort and satisfaction outside their own living environments. There are also many cases, where prostitutes enter the country as a traveler and later enter illegal prostitution. Another terrifying form of human trafficking is related to children, which are kidnapped while being on holidays with their parents or relatives.

Immigrant smuggling and related illegal activities are growing and so are the ways and forms of this crime. Organized crime groups often operate under the general travel mask and smuggle people into the country for further exploitation within prostitution and other crime forms. Illegal immigrants are depending on the so called protector who sees an emigrant as a work force or even their own property.

Car stealing and smuggling is typical mostly for destinations close to developed tourist markets. Many tourists would travel to those destinations with their own vehicles. Once stolen their cars get disassembled and sold for spare parts or smuggled to and sold in underdeveloped countries.

One of the rapidly developing forms of tourism related crime are ripping off loans, particularly common in emerging destinations with high investment needs and potentials. People see opportunities to invest in small businesses (e.g. bars, discotheques, restaurants, 
shops, small hotels etc.), but have no financial means. Interest rates for such quick loans are usually extremely high so in most cases the borrowers are unable to return the principal and they either lose their business or are forced to some illegal actions by the creditors. Ripping off loaning is quite popular in gaming destinations where lots of addicted players need quick cash. Another form of financial crime developed are collecting debts which are based solely on pressures, threatening and violence. This form of crime operates under the pretext of providing safety and protection from different oppressors.

Human organ trafficking is a relatively new form of crime. Organs are used for transplantations and medical experiments. Tourists usually act as organs seekers and not donors. Patients with sufficient material resources travel to foreign countries where they buy organs (mostly kidneys and livers) from donors who urgently need money. Budiani-Saberi and Delmonico (2008, p. 925) call this "transplantation tourism" and they add that there were cases, where tourist reported being a victim of such treatment. In some cases the tourists' adventurous spirit takes them to dangerous areas where they expose themselves to targeting groups and became victims of human organs trafficking.

Money laundering is a common name for all techniques used for exchanging illegally obtained wealth for fair and legal income. Crime groups involved in money laundering usually try to hide their criminal actions or simply abuse the taxation system. Tourism industry is a source of fast and large money turnover and despite global information and communication technology there is still a large portion of financial transactions done in traditional way (e.g. in cash). Such financial flows are ideal for money laundering. Many destinations with poor or no electronic payment systems use exchange bureaus or offices for money laundering. Many economic activities are involved in forgeries. Most problematic are credit cards forgeries which jeopardize the entire bank systems. In addition tourists are involved in trafficking of counterfeited products (e.g. music disks, clothes, jewelry and other accessories).

The above mentioned forms of organized crime related to tourism are only a few which are spread worldwide. Pizam (1999, p. 5) claims that there is not a single minute without a tourism related crime action being committed somewhere in the world. Additionally there are also numerous crime actions involving domestic population. Nevertheless, the theory and research, conducted on the topic of tourism related crime, teach us that there is a need to differentiate between the form of crime and its impact on destination choice. People would rarely move for the sake of the crime level in their home environments but they do select their travel destinations accordingly.

\section{Terrorism}

Tourism represents an integral part of the globalization (Tarlow, 2006, p. 45), the terrorism embodying its darkest side. As a result of globalization process tourism and terrorism became inevitably linked. By accessing the most advanced destruction technologies terrorist threats and consequences of terrorist attacks have became more powerful and effective than ever before. Recent terrorist activities caused the rise of precautionary measures at the airports and national borders, thus tourism is being affected as well. On the other hand, many tourist attractions are positioned close to politically and nationally important elements or statues; hence, tourist became easy terrorist target (Faulkner, 2001, p. 142).

By being one of the most important global economic activities tourism also became an interesting target for terrorists. It has been established already that terrorists seek their targets according to the importance within the targeted area, which economy always is. Tourism is also attractive to the media, hence it has immediate media attention and the latter is also something terrorists always look for. Richer (Sonmez \& Graefe, 1998, p. 119) claims that media interests for terrorists' political demands confirm the attractiveness of tourists areas for attacks.

There are three known forms of links between the terrorism and tourism (Pizam \& Mansfel, 2006, p. 4). Firstly tourist can becomevictimized by coincident or on purpose and the tourism infrastructure can be targeted by terrorists due to its attractiveness to the media. Tarlow (2006, pp. 45-46) considers aircrafts, major ships, coaches, restaurants and popular bars, events and venues for gathering large masses of visitors as most attractive terrorism targets. Among other reasons for 
such attractiveness Tarlow (2006, p. 44) mentions the hesitation of the tourism industry in offering resistance, as additional cause for their fragility. Tourism workers are usually afraid to take extra security measures because they might affect the demand and indirectly profits. As large industry, linking many different economies, tourism attracts terrorist groups, who seek to destroy important economies. Attacking tourism indirectly means attacking every single industry depending on it. Tourism is also attractive for media and terrorists seek media attention, yet another evidence of relations between the tourism and crime. Tourism involves important cultural and natural attractions which in most cases present the identity and history of each nation and again the identity is something terrorists and other crime groups are trying to damage. The last but not least important criterion for attractiveness of tourist sites for terrorist actions are masses of people at those places, so terrorists can easily disguise. Terrorism seeks targets meeting at least three out of four above mentioned criteria which tourist destinations easily meet (opportunity for large number of victims, opportunity for publicity and media coverage, opportunity for major economic damage and opportunity for identity or national symbols destruction).

\section{Wars}

There are a number of politically unstable regions and countries worldwide. The instability is caused by religious, ethnic, racial and other disputes or imbalances. Quite frequent instabilities involve regions of Middle East, Western Balkans, Kashmir, Caucasus, Korean peninsula and some others. Those areas are not isolated unstable areas but they do present a threat to wider regions and occasionally involve in military interventions, hence destabilize the country. Such circumstances are ideal for different forms of pressures on people and infrastructure and result in greater opportunities for development of organized crime.

Irrespective of their origins and backgrounds, wars impose great impact on the tourism demand, not only in close but wider areas if not on a global scale. As opposed to the terrorist attacks war breakouts affect wider regional areas and have far greater consequences on tourism than the terrorism (Pizam \& Mansfeld, 2006, p. 4).

\section{Social and political unrests}

Social and political unrests appear as military coups, violent demonstrations, uprisings and other forms of resistance. There are many potential reasons for such events (e.g. incompetent government, corruption, abuse of political power, weak state institutions and lack of responsibilities by the public sector) and in many cases they lead to the disintegration of the country or at least to collapse of the government. The latter is ideal for the development of war situations, terrorist actions, weapons smuggling and organized crime, which are all important factors for the development of insecure image thus affecting international attractiveness. These and similar social events or unrests will result in drop of international arrivals (Pizam \& Mansfeld, 2006, p. 4) irrespective of the real level of threats to the tourists.

Such and similar social and political unrests have indirect impacts on domestic as well as international tourism demand (Pizam \& Mansfeld, 2006, p. 4). Once details on riots enter international media they will immediately affect the destinations image even though there is no serious threat for the tourists. The final damage to the tourism depends on crisis management, which can mitigate most of the medium to long-term impacts and entirely focuses on strategies for recognizing and coping with unwanted events (Faulkner, 2011, p. 137). Without a proper crisis management destinations will face challenges to establish stable and positive tourism image, hence changing negative arrival trends into the positive ones.

Social and political unrests as well as minor indications to that will result in booking cancellations and amendments. Amendments usually reflect in transfers to other destinations and will negatively damage destinations under pressure as well as their close neighboring countries or regions.

\section{Environmental security threats}

End of the Cold War resulted in withdrawal of the serious military threats, hence the international politics movedits interests to other areas; one of them was environmental security. Hall and other (2003, pp. 7-8) identified at least four areas of relations 
between the traditional security and the concept of the environmental security. The first is the relation between the scarce natural resources and the increasing needs of the global society, another is the issue of biological weapons and climate changes and their impact on the natural environment. Additionally authors point out the impact of ecological migrations on the abandoned as well as newly occupied areas and, the last but not least, vast military facilities and infrastructure with nuclear, chemical and biological weaponry without or with weak security and surveillance.

Healthy natural environment is of the major importance for the development of tourism and attractive destination image. There are only few known travel market segments that would devote their travel budget and time for exploring abandoned, unfriendly and devastated areas around the world. In addition, one can experience unpleasant travel experience, which is caused by the political and other disputes at destination.

Climate changes cause natural disasters (e.g. earthquakes, flooding, hurricanes etc.) which destroy tourism infrastructure and indirectly cause important damage to the destination economy. There was some reporting of human casualties among tourists, as well as Murphy and Bayley (Faulkner, 2011, p. 142). Authors also claim that there is a connection between the attractiveness of destinations and their likelihood to be impacted by one of the natural disasters. This might indicate that tourism itself could be additional cause for such events.

Its sustainability and weight it imposes to the natural environment make the question of the environmental security even more important. Among different forms of the security threats the environmental ones are the most severe and in many cases irreparable. Environmental threats are difficult to control and limit within certain natural environment, hence development and growth have no limits. Major natural threats will damage wider geographical areas and rarely the national entities would be able to keep the negative natural impacts outside their borders, which is not the case with some other forms of security threats.

\section{Spread of infectious diseases}

Different diseases imposed the heaviest threat to the human kind for centuries (Hough, 2004, p. 154) and some still do so. Back in 14th century Plague demanded more lives than any other military conflict in the history of the humankind, in just 5 years. In the international and national security aspect infectious diseases have something in common with the natural threats. They both disregard political and natural borders and they spread much faster than other forms of threats. Hall claims that tourism presents one of the major reasons for infectious diseases spread. It is the borderless nature of the tourism that helps viruses and other vectors to be transported from one to another area (Rittichainuwat \& Chakraborty, 2009, p. 412). Among all known infectious diseases AIDS presents the most endangering one and in some areas (i.e. sub-Saharan Africa) it presents a threat greater than armed conflict, despite the level of military insecurity in the area. Hough (2004, p. 154) reports that about 23 million lives were lost because of the AIDS. There are particular and general travel motives which increase the level of threats to get affected by different viruses or diseases; hence tourism is the activity that generates transmitters as well as transmission.

In the last decade tourism suffered severely because of the infectious diseases (e.g. pig foot and mouth disease, mad cow disease, severe acute respiratory syndrome or SARS, bird flu etc.). World Health Organization reports that there are many other health related threats that shape the process of travelling and experiencing different tourist destinations. Diseases such as malaria, yellow fewer, cholera, tuberculosis, hepatitis and so on (Kou, 2008, p. 918) are the ones that most likely affect the modern tourist, which either becomes a victim or transmitter of the disease.

\section{Security and destination development}

The accumulated evidence through out the worlds hows that the impacts of security incidents on the tourism industry as a whole, in most cases, are negative and multifaceted. Consequently, impact concepts are divided here into four subgroups depicting different 
facets of the impact of security situations on tourism (authors talk about six subgroups). Each subgroup of concepts also includes commonly used variables that measure these impacts (Pizam \& Mansfeld, 2006, p. 6).

\section{Impact on the Destination Itself}

When at a certain destination a security incident happens, one of the first tasks of the local decision makers is to assess the damage. This response is needed in order to help in formulating contingency plans to handle and mitigate the damage to the local tourism industry (Pizam \& Mansfeld, 2006, pp. 6-7). Some of the commonest variables used for the purpose of assessing the impact of security incidents on a macro-level destination performance are:

- Tourist overall arrivals;

- Tourist arrival segmentation;

- Tourist overall receipts;

- Duration of recovery;

- Destination life cycle.

Therefore, the affected destinations play a key role in fighting for their economic and social survival especially in times of tourism security crisis (Pizam \& Mansfeld, 2006, p. 9).

As a result we can answer the two the main questions to be investigated in times of security crises i.e. (1) to what extent destinations are proactive or reactive as the crisis emerges; and (2) are destinations involved in a concerted multistakeholder (the tourism industry, local community, and the local/regional governments) effort to mitigate the consequences (Pizam \& Mansfeld, 2006, pp. 9-10).

\section{Impact on Tourists' Behavior}

Security incidents in most cases cause changes in tourists' behaviour and the perception of risk. Further on, all that is usually translated into travel decisions.The results could be in the form of cancellations of booked trips and avoiding the affected destination. In cases when the tourists are already at destinations, the proper step is moving to a safer place for evacuating the destinations (Pizam \& Mansfeld, 2006, pp. 6-7).
The most frequent variables used in pursuit of understanding tourists' reaction

to changing security situations are:

- Intention to travel to affected destination;

- Cancellations;

- Bookings;

- Avoidance of unsafe destinations;

- Destination choice.

However, at this stage it is important to note that measuring tourists'behavior following an important change in the security level of a given destination is imperative in order to formulate crisis-management plan (Pizam \& Mansfeld, 2006, p. 7).

\section{Impact on the Tourism Industry}

The impact of security incidents on the tourism industry can be enormous. Security incidents do affect tourism industry, but they also affect those sectors of economy that are directly or indirectly related to the tourism industry. This effect can either be large or small depending on the reliance on the tourism industry.

For leisure tourists on organized trips, the tourists' travel behaviour is facilitated by two stakeholders: tour operators in the generating markets and tour operators in the receiving destination.They share a common objective of minimizing the damage resulting from a change in the security situation of a given destination (Pizam \& Mansfeld, 2006, p. 7).

The most common variables used to characterize the behaviour of the tourism industry in the wake of evolving security situations are (Pizam \& Mansfeld, 2006, pp. 7-8):

- Evacuation of tourists by tour operators;

- Inclusion/exclusion of destination in tour operators' brochures;

- Cash flow;

- Profitability;

- Projection of destination image by tour operators and travel agents.

As a result of security incidents at tourist destinations the result is diminishing of tourist arrivals. The affected destinations consequently lose professional employees and entrepreneurs, who are crucial for the successful 
operation of the tourism industry. Therefore peace and safety are the primary conditions for successful tourism development (Pizam \& Mansfeld, 2006, p. 16).

\section{Media Behaviour}

The media are important news generators in case of security incidents. It is important that the media should produce accurate and real information. Indeed, in some cases it was evident that the information and assessment provided by the media a bout the severity of the incidents were incorrect and exaggerated about the real risk at the affected destinations.

In order to establish empirical evidence on this possible bias and in pursuit of objective assessment of media behavior in times of security induced tourism crisis, the following variables according to Pizam and Mansfeld (2006, p. 9) may be useful:

- Extent of coverage of the incident;

- Types of media coverage;

- Biased information and interpretation of security situations;

- The impact of media warnings.

Electronic live media coverage causes the most detrimental effect on tourists'perception of risk and on the image of affected destinations (Pizam \& Mansfeld, 2006, p. 17).

\section{Conclusions}

Tourism is one of the major economic pillars of many world countries and, additionally, more and more countries admit that. Number of people being able to afford traveling rises not only due to personal income but also due to changes on the supply market. The most significant changes happened in the air industry, either by introducing low cost carriers who offer low budget travelling or by new aircraft technologies enabling longer and nonstop routes. World became the socalled global village, however not always with positive consequences. Security issues around the globe affect tourism industry on local as well as global level, not only by reducing demand but also guiding it, hence causing over or under demand pressures. Crime, wars, social and political unrests, environmental threats and spread of infectious diseases are just some of most common forms of threats to the safe and secure tourism. Mass media and other forms of modern communication technology spread information on potential risk in no time, meaning that just moments after particular security risk appears, travel flows will change. On the other hand sometimes unconfirmed and not verified information will circle the world and cause irreparable damage to the tourism industry and destinations images.

Nowadays people are much more aware of the security issues and their potential risk to their own safety. Even small imbalances will temporarily or permanently change travel flows to endangered areas. Most significant changes are travel postponements or cancellations. Even a slight threat will damage destination's image and tourists will develop a negative attitude towards visiting such destination, which results in arrivals decline (Richard, 2002, p. 577). Beirman (in Rittichainuwat \& Chakraborty, 2009, p. 411) claims that safety and security issues are an important factor of destination choice either due to the tourist's personal safety concern or simply due to the alternative options at safe destinations (Čavlek, 2002, p. 482). Supply of travel opportunities and destinations is diverse and tourist can choose among many different destinations, thus avoiding any risks is simple.

All forms of security incidents have negatively affected their image and can cause a decline in tourist arrivals. Personal security is increasingly important for tourists. Therefore the tourists will seek safe and secure destinations and avoid those that have been plagued by all sorts of violent incidents. Primary conditions for successful tourism development are peace, safety, and security. And media have also important role for successful development of tourist destinations, especially by providing accurate and real information (Pizam \& Mansfeld, 2006, pp. 14-17).

In general we can conclude that security is a basic predisposition for prospective destination development, however it is not the only one. Despite the fact that our sample cannot be representative for the entire country, we can assume that results can be generalized. Slovenia is considered to be a safe country and majority of the population travels to neighboring countries (e.g. Croatia, Austria, and northern (taly) or they take travel packages 
to secured travel resorts in northern Africa (e.g. Egypt, Tunisia) and Spanish islands. Such travel culture suggests lack of experiences of true security risks while travelling; hence the travel security culture is not yet developed. There is a chance that, due to the transnational nature of the security threats, relative safety can change into threat over the night.

\section{REFERENCES}

Adamoli, S., Di Nicola, A., Savona, E. U., \& Zoffi, P. (1998). Organized Crime Around the World. Helsinki: European Institute for Crime Prevention and Control.

Alsarayreh, M. N., Jawabreh, O. A. A., \& Helalat, M. S. (2010). The influence of Terrorism on the International Tourism Activities. European Journal of Social Sciences, 13(1), 145-160.

Blake, A., \& Sinclair, M. T. (2002). Tourism Crisis Management, Responding to September 11. Nottingam: Christel De Haan Tourism and Travel Research Institute.

Brunt, P., Mawby, R., \& Hambly, Z. (2000). Tourist victimization and the fear of crime on holiday. Tourism Management, 21, 417-424.

Budiani-Saberi, D.A., \& Delmonico, F.L. (2008). Organ Trafficing and Transplantation Tourism: A Commentary on the Global Realities. American Journal of Transplantation, 8, 925-929.

Cothran, C. A., \& Cothran, C. C. (1998). Promise or Political Risk for Mexican Tourism. Annals of Tourism Research, 25(2), 477-497.

Čavlek, N. (2002). Tour operators and destination safety. Annals of Tourism Research, 29(2), 478-496.

Dobovšek, B. (2005). Organizirani kriminal kot peta veja oblasti. In G. Meško, M. Pagon and B. Dobovšek (Ed.). Izzivi sodobnega varstvoslovja (pp.299-312). Ljubljana: Fakulteta za policijskovarnostne vede.

Faulkner, B. (2001). Towards a framework for tourism disaster management. Tourism Management, 22, 135-147.

Goodrich, J.N. (2002). September 11, 2001 attack on America: a record of the immediate impacts and reactions in the USA travel and tourism industry. Tourism Management, 23, 573-580.

Hall, C. M., Timothy, D. J., \& Duval, D. T. (2003). Security and Tourism: Towards a New Understanding? In C. M. Hall, D. J. Timothy in D. T. Duval (Ur.). Safety and Security in Tourism (pp.1-18). New York: The Haworth Press Inc.

Hough, P. (2004). Understanding Global Security. London and New York: Routledge.

Kuo, H. I., Chen, C. C., Tseng, W.C., Ju, L. F., \& Huang, B. W. (2008). Assessing impacts of SARS and Avian Flu on international tourism demand to Asia. Tourism Management, 29, 917-928.
Kurež, B., Mekinc, J., \& Anžic, A. (2009). Človekove pravice v luči novih groženj varnosti. Teorija in praksa, 46(5), 170-185.

Lubi, D. (2004). Teorija strategije. Študijsko gradivo. Ljubljana: Fakulteta za družbene vede.

Mansfeld, Y., \& Pizam, A. (2006). Tourism, Security \& Safety. Oxford: Elsevier Inc.

Mihalič, T. (1996). Tourism and Warfare. The Case of Slovenia. In A. Pizam in Y. Mansfeld (Ed.), Tourism, Crime and International Security Issues (pp.231-246). New York: Wiley.

Ovsenik, M. (1999). Osebna varnost kot dejavnik v turizmu. In A Anžič (Ed.), Varnost in turizem (pp. 289-303). Ljubljana: Visoka policijsko-varnostna šola.

Pečar, J. (1999). Viktimološki pogledi na turizem - turistična kriminaliteta. In A. Anžič (Ed.), Varnost in turizem (pp 315-328). Ljubljana: Visoka policijsko-varnostna šola.

Pizam, A. (1999). A Comprehensive Approach to Classifying Acts of Crime and Violence at Tourism Destinations. Journal of Travel Research, 38(1), 5-12.

Pizam, A., \& Mansfeld, Y. (2006). Toward a Theory of tourism Security. In Y. Mansfeld and A. Pizam (Ed.), Tourism, Security \& Safety (pp. 1-28). Oxford: Elsevier Inc.

Richard, G. (2002). Tourist's perception of safety and security while visiting Cape Town. Tourism Management, 24, 575-585.

Rittichainuwat, B. N., \& Chakraborty, G. (2009). Perceived travel risk regarding terrorism and disease: The case of Thailand. Tourism Management, 30, 410-418.

Sönmez, S. F. (1988). Tourism, Terrorism, and Political Instability. Annals of Tourism Research, 25(2), 416-456.

Sönmez, S. F., \& Graefe, A. R. (1998). Influence of terrorism risk on foreign tourism decision. Annals of Tourism Research, 25(1), 112144.

Tarlow, E. P. (2006), A Social Theory of Terrorism and Tourism. In Y. Mansfeld and A. Pizam (Ed.), Tourism, Security \& Safety (pp.3348). Oxford: Elsevier Inc.

UNWTO (2007). http://unwto.org/facts/eng/pdf/indicators/ITA_ Americas.pdf, accessed on 22.10.2007

http://24ur.com/novice/svet/delo-upocasnjuje-radioaktivna-voda. html, accessed on 28.3.2011.

http://en.rian.ru/world/20110203/162427405.html, accessed on 28.3.2011.

http://en.wikipedia.org/wiki/Drug_tourism, accessed on 23.3.2011.

http://www.allvoices.com/contributed-news/8057707-at-least150-people-were-killed-and-500-others-missing-in-egypt, accessed on 28.3.2011 
Kurež, B., Prevolšek, B. - Influence of security threats on tourism destination development 2015. Fakultet za sport i turizam, Novi Sad, TIMS Acta 9, 159-168

http://www.eturbonews.com/21877/japan-tourism-versus-tsunami, accessed on 28.3.2011.

http://www.justlanded.com/english/Italy/Articles/Culture/Crime-inItaly, accessed on 23.3.2011.

(http://www.sourcejuice.com/1016841/2006/04/18/Carryingfake-brand-name-may-subject-heavy-fines-Europe/, accessed on 23.3.2011.

http://www.state.gov/r/pa/ei/bgn/5286.htm, accessed on 24.3.2011.

http://www.stat.si/letopis/2010/25_10/25-02-10.xls, accessed on 28.3.2011.

http://www.stuff.co.nz/national/43427, accessed on 24.3.20111.

http://www.washingtonpost.com/world/death-toll-from-japansdisasters-over-8000-more-than-12000-missing/2011/03/20/ ABF4yV0_story.html, accessed on 28.3.2011.

Datum prijave rada: 21.04.2015.

Datum prihvatanja rada: 29.04.2015.

\section{Kontakt}

Bojan Kurež, Fakulteta za turizem, Univerza v Mariboru Cesta prvih borcev 36, Brežice, Slovenija

E-mail: bojan.kurez@um.si

Boris Prevolšek, Fakulteta za turizem, Univerza v Mariboru, Cesta prvih borcev 36, Brežice, Slovenija

E-mail: boris.prevolsek@um.si 